\title{
Formation of a new tax regulation tool in the form of self- employment in rural areas
}

\author{
T. V. ZYRYANOVA ${ }^{1}$, E. M. KOT ${ }^{1}$, A. O. ZAGURSKIY ${ }^{1}$, S. B. ZYRYANOV ${ }^{2}$ \\ ${ }^{1}$ Department of accounting and audit, Institute of Economics Finance and management, Ural \\ State Agrarian University, Sverdlovsk region, Yekaterinburg, Karl Liebknecht street 42, 620075, \\ RUSSIA \\ ${ }^{2}$ Department of technosphere and environmental safety, Ural State Agrarian University, \\ Sverdlovsk region, Yekaterinburg, Karl Liebknecht street 42, 620075, RUSSIA
}

Abstract. 2019 marked the beginning of the tax on professional income. This tax regime is new in the Russian tax system and is characterized by its universality. Previously, there were no such regulatory mechanisms in Russian practice. In this article, the authors assess the prospects for introducing a tax on professional income among private farms as a new regulatory mechanism. The authors estimate the number of potential taxpayers-private farms in the Russian regions. The author's software offers methods to encourage private farms to apply the new tax regime and ways to improve the new tax mechanism in the agricultural environment.

Key words: tax on professional income, personal subsidiary farms, self-employed citizens, state tax regulation, value added tax.

Received: October 2, 2019. Revised: April 8, 2020. Accepted: April 29, 2020. Published: May 11, 2020.

\section{Introduction}

In regulating the activities of agriculture, it is necessary to remove from the shadows the activities of private farms (hereinafter - PF), aimed at the sale of actually produced products. The importance of this process is that the agricultural sector is one of the leaders in the share of the shadow sector. Thus, according to Rosstat, the share of shadow operations in the gross value added of agriculture is $38.1 \%$, and in relation to the gross domestic product (hereinafter-GDP) is $1.4 \%$. This phenomenon is explained by the fact that in agriculture there is a high level of informal production, i.e. quite legal, but nowhere fixed production of agricultural products for the purpose of market sales of manufactured products.

The state policy in the field of tax regulation and taxation of agriculture must, among other things, focus on the full inclusion of agricultural land in the system of tax relations when applying the new tax regime.

In the authors ' understanding, tax regulation is an indirect means of regulating the economy, implemented through the use of such mechanisms as the tax rate, special tax regimes, benefits and reduced tariffs. The mechanisms are applied depending on the types of taxpayers.
The lack of proper measures of state tax regulation of economic activities of agricultural enterprises has led to the fact that the agricultural sector is one of the leading sectors of the Russian economy in terms of the share of the shadow sector.

The state's goals in this regard are quite simple. Increasing the number of self-employed is part of the national project for small business development.

\section{Materials and methods}

Formation of a new tax regime. On November 27, 2019, Federal law No. 422-FZ (hereinafter referred to as the Law) initiated a tax experiment to establish a new special tax regime "Tax on professional income" (hereinafter referred to as the TPI) . In the first year of operation, four Russian regions, namely Moscow, the Moscow region, the Kaluga region and the Republic of Tatarstan, became the testing area for the new tax regime.

The main goal of the experiment is to enable some entrepreneurs not to form a legal entity, but at the same time to legalize their income.

By its specifics, this tax regime is new in the Russian system of taxation and tax regulation. Its peculiarity is its focus on individuals, including individual entrepreneurs who do not work under labor contracts and do not attract 
employees. The target group of the new regime can be described as individuals who earn their own labor and perform work in person[1],[2],[3],[4].

The law introduced a new term "professional income" into the practice of tax relations, which is understood to mean the income of an individual from independent activities in which he does not have an employer and does not attract employees under employment contracts, as well as does not have income from the use of property.

New target group of taxpayers is singled out from the provisions of the law on TPI, which the tax system characterizes as self-employed citizens who have the right to switch to paying TPI if they meet the criteria defined by tax legislation, namely:

1) do not sell excisable goods;

2) do not resell goods;

3) do not engage in mining;

4) do not have employees;

5) do not conduct business activities in the interests of other persons on the basis of assignment agreements, Commission agreements or Agency agreements;

6) do not provide services for the delivery of goods with the acceptance of payments in the interests of other persons;

7) do not apply other special tax regimes and do not conduct business activities, the income from which is taxed on personal income.

The most important criterion that self-employed persons must meet in order to have the right to apply the TPI is the level of profitability taken into account when determining the tax base, which for a calendar year for a self-employed person should not exceed 2.4 million rubles.

With this restriction, an important advantage of the TPI in income taxation is the application of significantly low tax rates, namely $4 \%$ for income received from individuals and $6 \%$ for income received from legal entities and individual entrepreneurs (hereinafter referred to as individual entrepreneurs). In addition, the law provides for a tax deduction for the amount of tax in the amount of 10,000 rubles.

Other methods of self-employed benefits are used in the US tax system. However, the US approach has a different operating principle, namely, the self-employed are given the opportunity not to pay income tax, if the income for the year does not exceed $\$ 400$.

But the main feature of the new tax regime is the procedure for reporting to the tax authority, namely that the provision of a tax return is not provided.

The interaction with the tax authority itself takes place through the use of the mobile application "My tax" (hereinafter - the mobile application), by transmitting information through the mobile application to the Federal tax service (hereinafter - the tax authority) when making calculations. Based on the received data, the tax authority calculates the tax when applying automated procedures. Payment of the tax is made on a notification basis using the mobile app.

It should be noted that the new tax regime does not differentiate approaches to regulating various sectors of self-employment, but uses uniform, unified rules of work.

In the new tax regime, in addition to removing the economic activities of citizens from the shadows and imputing to them the constitutional obligation to pay taxes, we see the formation of a new tool for tax regulation. The most effective economic impact of the new tool can have on the agricultural sector of the Russian economy, namely the involvement in economic turnover of such forms of self-employment in rural areas as personal subsidiary farms of citizens (hereinafter $\mathrm{PF})$.

Scientific view on self-employment in agriculture. According to V. V. Paciorkovsky, it is correct to consider PF as a sphere of selfemployment from a methodological point of view. The author notes the increasing dynamics of the processes of institutionalization and deshadowed of the self-employment sector, while actualizing the inevitability of these processes affecting rural areas, noting the fallacy of putting self-employment in the same row with self-employment in other industries [5]. 
It is impossible to form a stable economy, economic relations and territorial community of rural territories based on "individual farmers"[6],[7],[8],[9]. According to official statistics, in the structure of agricultural products in 2018 , the share of private farms was $31 \%$, for comparison, the share of peasant farms (hereinafter - FE) is $13 \%$. Moreover, in comparison with both agricultural organizations and individual entrepreneurs, and with farms, PF have a positive index of agricultural production, which is $100.2 \%$, and in the subjects of the Russian Federation of the far Eastern Federal district, this index exceeds 109\%.

We see a growing activity of PF in the population. However, we note that the main part of the products produced by PF is used by citizens for their own consumption, ensuring their needs for food supply [10]. However, the other part of the agricultural products of PF goes to further sale to the population and business entities [11].

The basis for the introduction of a tax on professional income in the agricultural sector of the economy. According to the Results of the all-Russian agricultural census of 2016 (hereinafter referred to as the agricultural census), as of July 1, 2016, 23496.9 thousand personal subsidiary and other households of citizens were functioning in Russia, of which 18752.4 thousand or $80 \%$ were producing agricultural products. At the same time, 2334.3 thousand or $13 \%$ of agricultural enterprises produce agricultural products for an additional source of money, while 55.7 thousand or $0.3 \%$ of agricultural enterprises are the main source of income.

There is a significant potential for implementing NAPs in the agricultural structure of the selfemployed sector[12],[13].

Following the results of the first year of application of the new regime, the TPI showed its ability to bring independent production activities of citizens into the official format of work, as a result of which the geography of its application was expanded to 19 more regions , including the Middle Urals. The number of subjects of the Russian Federation applying this regime has increased to 23 . This mode will be valid for 10 years.

Let's consider the possibilities of each of the regions in terms of the potential for implementing TPI in the PF environment. For these purposes, we use the data of the agricultural census, in terms of the number of farms that produce agricultural products to generate cash income (see table. 1).

Table 1. The number of agricultural enterprises in the regions of the Russian Federation-the territories of the experiment, for which the sale of agricultural products is a source of money

\begin{tabular}{|l|c|}
\hline \multicolumn{1}{|c|}{ Subject of the Russian Federation } & $\begin{array}{c}\text { Quantity of PF that sell } \\
\text { agricultural products }\end{array}$ \\
\hline Moscow & 0,2 \\
\hline Moscow region & 12,6 \\
\hline Kaluga region & 4,9 \\
\hline Republic of Tatarstan & 166 \\
\hline Saint-Petersburg & 0 \\
\hline Volgograd region & 30,9 \\
\hline Voronezh region & 90,7 \\
\hline Leningrad region & 4,5 \\
\hline Nizhny Novgorod region & 46,5 \\
\hline Novosibirsk region & 26,3 \\
\hline Omsk region & 38,6 \\
\hline Rostov region & 89 \\
\hline Samara region & 45,2 \\
\hline Sakhalin region & 1,1 \\
\hline
\end{tabular}




\begin{tabular}{|l|c|}
\hline \multicolumn{1}{|c|}{ Subject of the Russian Federation } & $\begin{array}{c}\text { Quantity of PF that sell } \\
\text { agricultural products }\end{array}$ \\
\hline Sverdlovsk region & 12,9 \\
\hline Tyumen region (without Autonomous districts) & 15,8 \\
\hline Chelyabinsk region & 39,8 \\
\hline Krasnoyarsk region & 18,2 \\
\hline Perm region & 18,5 \\
\hline Nenets Autonomous district & 0 \\
\hline Khanty-Mansi Autonomous district -Yugra & 1,5 \\
\hline Yamalo-Nenets Autonomous district & 2,2 \\
\hline Republic of Bashkortostan & 196 \\
\hline Subtotal & $\mathbf{8 6 1 , 4}$ \\
\hline
\end{tabular}

The results obtained show the number of potential TPI payers among PF. The republics of Tatarstan and Bashkortostan have the greatest

\section{Resultand discussion}

\begin{abstract}
Author's proposals for the introduction of a tax on professional income in the agricultural sector. The importance of involving citizens in independent production activities is reflected in the set of measures for the implementation of the national project "Small and medium-sized businesses and support for individual business initiatives" in accordance with the decree of the President of the Russian Federation on national goals and strategic development objectives.
\end{abstract}

We can see the growing importance and importance of involving PF in the system of tax relations through the application of a new special tax regime.

Quite often there are economic relationships between organizations-producers and sellers of food and agricultural products with the population of rural areas for the purchase of products. Such procedures have a special status for the application of indirect taxation, namely the calculation and payment of VAT.

In accordance with paragraph 4 of article 154 of the tax code of the Russian Federation, organizations that have purchased agricultural products and products of their processing from individuals-citizens, in the subsequent resale of such products, can calculate VAT from the interprice difference, i.e. from the difference between the sale price and the purchase price: potential in this area, which characterizes their features that must be taken into account when conducting tax policy.

$\mathrm{Tb}=(\mathrm{Pp}-\mathrm{Sp})$,

where:

$\mathrm{Tb}$ - tax base;

$\mathrm{Sp}$ - selling price;

$\mathrm{Pp}$ - purchase price;

This procedure allows you to calculate and pay VAT in a smaller amount, since the tax in this case is calculated not from the cost of products sold, but from the inter-price difference [14].

However, there are a number of conditions under which this method of calculating the tax base can be calculated if:

1) products are purchased from individuals;

2) the purchased products are agricultural or processed products;

3) the purchased products are included in the list approved By the government of the Russian Federation;

4) the purchased products are not excisable.

Such a method of calculating VAT can only be used if agricultural products are purchased from individuals who are not VAT payers, i.e. from private households.

As we assume, in order to encourage PF to register as a payer of the TPI, it is possible to 
Supplement the conditions for applying a special procedure for determining the tax base by including requirements that an individual from whom agricultural products are purchased must be registered as a payer of the TPI. Similarly, it will ensure the relevance of the PF to register as a TPI payer.

For a wider involvement of agricultural enterprises in the economic turnover, we also offer the possibility of calculating the tax base for VAT from the inter-price difference not only for organizations and individual entrepreneurs engaged in the resale of purchased agricultural products, but also for producers who use these products for processing.

Similar attempts to expand the way VAT is calculated and paid have been applied before. So, in 2013, the draft Federal law N 200574-6 "on amendments to articles 154 and 164 of part two of the Tax code of the Russian Federation" was submitted to the State Duma, in which it was proposed to add the words "as well as products made from agricultural raw materials" after the words "when selling agricultural products and products of its processing" [15].

Author's proposals for the institutionalization of the tax on professional income in the agricultural sector. Moreover, it is necessary to ensure that the TPI is institutionalized so that its payers acquire the official status of a business entity, which in the future will provide them with a number of appropriate opportunities.

For example, when organizing rural fairs and exhibitions by government authorities, it is necessary to provide a mandatory condition for the participation of PF of the population, namely to be registered as a payer of the TPI. Such recommendations can be used by both state and local authorities.

The advantage of participation of $\mathrm{PF}$ - payers of TPI in commercial and economic operations is that they do not need to use cash registers, and the formation of the receipt and its transfer to the buyer occurs using a mobile application.

However, it is necessary to make some adjustments in the conditions of application of the TPI. The absence of employees is a prerequisite for applying the TPI. In this part, we propose to make certain clarifications, namely, that it is allowed to use third-party labor at the conclusion of a civil contract (hereinafter-CCC), provided that these relationships are not regular and do not have the nature of an employment relationship. We justify this thesis by the fact that a significant number of agricultural enterprises attract labor to perform agricultural work. According to the agricultural census data, 2307.1 thousand farms in 2015 attracted employees to perform agricultural work, which is caused by objective reasons-the peculiarities of agricultural production. Such relationships based on the TPI should be considered as services provided in relation to $\mathrm{PF}$ that do not characterize the employment relationship. Similar measures should be taken with respect to the participation of family members of the TPI payer.

Professional income tax and other taxes. The law provides for the possibility for agricultural producers to switch from paying the unified agricultural tax (hereinafter referred to as the UACT) to paying the TPI in a notification manner. In this case, special conditions are provided in case of loss of the right to apply the TPI. In the event of such a loss, it is possible to switch to payment of other special tax regimes, including payment of the UACT, on a notification basis.

However, we note that in any case, the TPI for $\mathrm{PF}$-agricultural producers is not and cannot become an alternative to the UACT, since it is applicable only to a certain target audience of users for whom agricultural activity is not the only and main source of income. We argue this thesis, first of all, by the limited level of income, since the right to apply the TPI is limited by the level of profitability of 2.4 million rubles. So according to statistics of the Federal tax service, the average amount of income of IE and FE, payers and submitting UACT non-zero Declaration is almost 5,3 million rubles despite the fact that UACT does not imply any restrictions on the level of profitability and the availability of employees.

Therefore, there are at least three significant advantages to the tax on professional income.

First, it is an opportunity to work without fear of administrative or criminal liability.

Secondly, it will be easier to get a loan, since the legalization of income will help an individual to confirm their solvency to the Bank. 
Third, self-employment can be combined with work under an employment contract.

And again: $4-6 \%$ is less than the personal income tax at the rate of $13 \%$. For example, earnings are about 1 million rubles per year. Deductions to the tax authorities will amount to 40,000 rubles, which is higher than the average monthly salary in the Urals, which is currently 39700 rubles.

\section{Conclusion}

According to unofficial data, today every tenth Ural citizen works for himself. In this regard, there are concerns: whether the Federal tax service will start catching people who do not pay the new tax.

There are many ways to track them. At the request of the tax authority, banks are required to provide information about their clients ' financial transactions. If a person who does not work anywhere regularly receives payments to their account, this is an occasion to check their income. You can make control purchases of products based on ads on websites and social networks.

But it should be borne in mind that the new tax was declared voluntary at the Federal level.

Other advantages include the ability to place ads openly without fear of checks and fines, as well as expanding the customer base at the expense of large clients (usually they work officially).

According to the calculations of the Ministry of economic development of the Russian Federation, by the end of 2024, 2.4 million selfemployed people should be registered in the country. For the Middle Urals, this figure is 67.6 thousand people, and at the end of 2020 - about 35 thousand people.

Summing up, we note that the formation of a tax mechanism for regulating agricultural activities of citizens is an important step towards the development and formation of modern forms of economic relations that will create a consensus between the interests of the state, business and citizens. In our opinion, the introduction of the TPI mechanism is an important and promising step in this direction, allowing you to bring out the shadow of the activities of PF with the ability to pay VAT on preferential terms and receive other, above-mentioned preferences.

European countries have a good experience in developing the Institute of self-employed. In the countries of the European Union, in the period of the 1970s-1980s, programs to support selfemployed persons were not aimed at legalizing the already established self-employment of the population, but at helping the unemployed to form their own microenterprises. At the same time, self-employment was considered as an entrepreneurial activity with the use of their own labor. Institutional forms were aimed at helping the population to create small businesses. Today, self-employment in the EU countries covers $5.6 \%$ of the total population[16]. Thus, one of the solutions to support the self-employed can be the European experience.

\section{Acknowledgement}

This article was published in the framework of the scientific and practical conference "from inertia to development: scientific and innovative support of agriculture", dedicated to the 80th anniversary of the Ural state agrarian University.

\section{References:}

[1] Loshakov E. Tax on professional income // Labor law. 2018. N 12. P. 107 - 112.

[2] Hrinchenko R. V. DETECTION OF CHANGES AND THEIR CAUSES IN THE ENVIRONMENT OF THE ENTERPRISE. // Wschodnioeuropejskie Czasopismo Naukowe (East European Scientific Journal) \#6(46), 2019. P. 18-21.

[3] Bukina A. S. Rakhimova A. R. Chernousova K. S. TAX ON self-EMPLOYED CITIZENS: an EXPERIMENT IN RUSSIA, ANALYSIS of CURRENT PRACTICE // EScio. 2019. No. 6 (33).

[4] Maltseva E. N. Nikonova N. P. LEGAL STATUS of PROFESSIONAL INCOME TAX PAYERS in the LIGHT of the FEDERAL LAW ON the introduction of an EXPERIMENTAL SPECIAL TAX REGIME: THEORETICAL and LEGAL ASPECT // Baltic humanitarian journal. 2019. No. 2 (27) volume 8. Pp. 157-159.

[5] Khodorkovsky V. V. self-Employment in the agricultural economy: current research issues/ / Nikonovsky readings. 2018. No. 23. Pp. 182-184.

[6] Thomas Markussen, Maria Fibak, Finn Tarp, Nguyen Do Anh Tuan, The Happy Farmer: Self-Employment and Subjective Well- 
Being in Rural Vietnam // Journal of Happiness Studies. 2018. P. 1613-1636.

[7] Holly Ledornu Deekor The Role of Agricultural Entrepreneurship Educa Employment Generation and Community Empowerment // World Journal of Entrepreneurial Development Studies. 2019. No. 1. P. 6-11.

[8] Karp I. M., Virkovska A. A. LOGISTICS IN the GLOBAL FOOD INDUSTRY // Wschodnioeuropejskie Czasopismo Naukowe (East European Scientific Journal) \#12(40), 2018. P. 34-37.

[9] Departing A. N. Simonovska N. In. LEGAL CONSCIOUSNESS of self-employed people // the Power. 2019. No. 2. Pp. 176-183.

[10] Laipanova Z. M. PERSONAL SUBSIDIARY FARMS: ADVANTAGES, DISADVANTAGES AND DIFFERENCES FROM PEASANT (FARM) FARMS // Moscow economic journal. 2019. No. 11.

[11] Zyryanova T. V., Zagurskiy A. O. TAX ASPECTS OF STATE REGULATION OF SMALL FARMS IN AGRICULTURE // Wschodnioeuropejskie Czasopismo Naukowe (East European Scientific Journal) \#12(40), 2018. P. 38-41.

[12] Kaminova A. Yu. Zakharieva D. G. ANALYSIS of the INTRODUCTION of a NEW

TAX REGIME FOR self-EMPLOYED CITIZENS in the Russian Federation // Economics and business: theory and practice. 2019. No. 1. With.

[13] Sobol O. S. TAX on PROFESSIONAL INCOME IN the system of SPECIAL TAX REGIMES: an EXPERIMENT in LEGAL SUPPORT // Bulletin Of the Kutafin University. 2019. No. 7(59). Pp. 104-111.

[14] Grishina O. p. Features of VAT payment when selling agricultural products purchased from the population // VAT: problems and solutions. 2017. N 11. P. 27 - 33.

[15] Komarova I. N. Buying agricultural products from the population // Food industry: accounting and taxation. 2013. N 12. Pp. 12-24; 2014. N 1. Pp. 31-44; N 3. P. 9 - 19.

[16] Grabova O. N., Suglobov A. E. Problems of "out of the shadow" of selfemployed persons in Russia: risks and ways to overcome them // Economics and management. 2017. No. 6. Pp. 108-116. 